
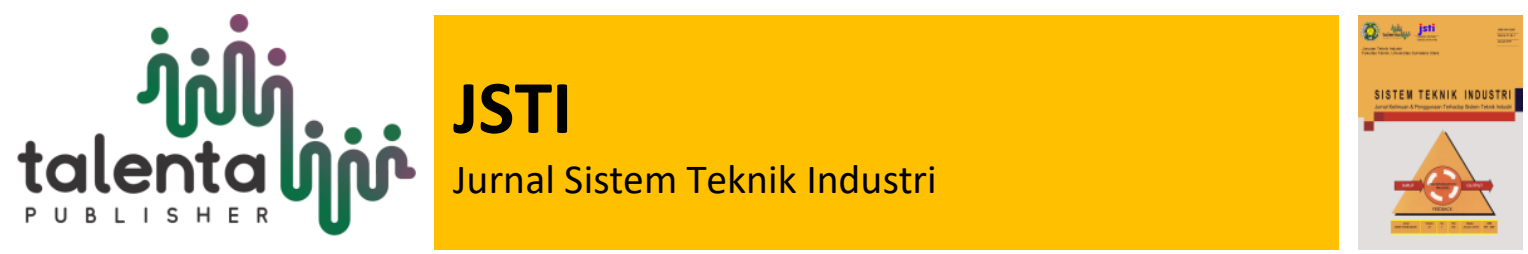

\title{
Pengukuran Beban Kerja Mental Bagian Marketing PT. Pindo Deli di Masa Covid-19 dengan Metode NASA TLX
}

\author{
Nana Rahdiana', Afif Hakim², Sukarman ${ }^{3}$ \\ ${ }^{1,2}$ Program Studi Teknik Industri, Universitas Buana Perjuangan Karawang, Jawa Barat 41361 \\ ${ }^{3}$ Program Studi Teknik Mesin, Sekolah Tinggi Teknologi Wastukencana, Purwakarta, Jawa Barat 41151
}

\begin{abstract}
PT. Pindo Deli is a national company that produces paper, which is located in Kutamekar Village BTB6/9, Karawang Regency, West Java. It produces various types of paper with a market share of $60 \%$ for exports and $40 \%$ for domestic. The condition of the Covid-19 pandemic also has an impact on the marketing and sales of paper, namely a decrease in the number of requests from the export and domestic markets. This condition certainly has affected the marketing department because it is still determined to be able to sell paper to the market. Job as marketing tend to have a high risk of mental workload, because they are required to always involve the brain's performance in completing their work. The purpose of this study is to measure the level of mental workload in the marketing department at the manager level, namely the regional managers and product managers in meeting their job demands, especially during the Covid-19 pandemic. The method used to measure the mental workload of managers is NASA TLX method. From the research results, it is found that $42 \%$ of manager had a high level of mental workload and the remaining $58 \%$ were in the very high category.
\end{abstract}

Keyword: Marketing, Manager, NASA TLX, Mental Workload

Abstrak. PT. Pindo Deli merupakan sebuah perusahaan nasional yang memproduksi kertas lokasinya terletak di Desa Kutamekar BTB6/9, Kabupaten Karawang, Jawa Barat. Produk yang dihasilkan adalah berbagai macam jenis kertas dengan pangsa pasar $60 \%$ ekspor dan 40\% domestik. Kondisi pandemic Covid-19 tetunya juga membawa dampak pada pemasaran dan penjualan kertas, yaitu penurunan jumlah permintaan dari pasar ekspor dan domestik. Kondisi ini tentu sangat mempengaruhi bagian marketing karena tetap dituntut untuk tetap dapat menjual kertas ke pasar. Pekerjaan sebagai marketing cenderung memiliki risiko beban kerja mental yang tinggi, karena mereka dituntut untuk selalu melibatkan kinerja otak dalam menyelesaikan pekerjaannya. Tujuan dari penelitian ini adalah untuk mengukur seberapa besar tingkat beban kerja mental bagian marketing pada tingkat manajer, yaitu para regional manager dan product manager dalam memenuhi tuntutan pekerjaannya khususnya selama pandemic Covid-19. Metode yang digunakan untuk mengukur beban kerja mental para manajer marketing ini adalah metode NASA TLX. Hasil penelitian ini sebanyak 42\% manager dengan tingkat beban kerja mental tinggi dan sisanya 58\% kategori sangat tinggi.

Kata Kunci: Marketing, Manager, NASA TLX, Beban Kerja Mental

Received 10 November 2020 | Revised 30 December 2020 | Accepted 20 January 2021

*Corresponding author at: Universitas Buana Perjuangan Karawang, Karawang, Jawa Barat, Indonesia

E-mail address: nana.rahdiana@ubpkarawang.ac.id https://doi.org/10.32734/jsti.v23i1.4873 


\section{Pendahuluan}

PT. Pindo Deli adalah sebuah perusahaan yang memproduksi berbagai macam jenis kertas, lokasinya terletak di Desa Mutamekar BTB 6/9, Kecamatan Ciampel, Kabupaten Karawang, Jawa Barat. Segmentasi pasar dari penjualan kertasnya adalah $60 \%$ untuk pasar internasional dan $40 \%$ untuk pasar domestik.

Namun sejak awal Maret 2020, dunia dihebohkan dengan adanya wabah virus corona yang berasal dari China, yang kemudian lebih dikenal dengan istilah Covid-19. Organisasi Kesehatan Dunia (WHO) telah menetapkan status gawat darurat global untuk wabah virus corona, dan dikategorikan sebagai pandemi. Selain menciptakan krisis kesehatan global, upaya supresi dan mitigasi pandemi Covid-19 juga menimbulkan disrupsi yang kuat pada tatanan perdagangan internasional [1]. Dari sisi permintaan (demand), kebijakan lockdown dan working from home (WFH) yang diterapkan hampir seluruh negara dampaknya juga dirasakan oleh PT. Pindo Deli, yaitu penurunan jumlah permintaan kertas dari pasar internasional dan domestik. Kondisi ini tentu sangat mempengaruhi bagian marketing karena tetap dituntut untuk tetap dapat menjual kertasnya ke pasar.

Mereka yang bekerja di bagian marketing diharuskan memenuhi target penjualan yang telah ditentukan perusahaan untuk setiap bulannya. Dalam waktu yang relatif singkat pola pemasaran pun berubah drastic, terlebih ketika pemerintah memberlakukan kebijakan "Pembatasan Sosial Berskala Besar" (PSBB). Marketing harus puter otak untuk bisa tetap memasarkan kertas ke konsumen. Marketing cenderung stres, memiliki risiko beban kerja mental yang tinggi, antara tuntutan pekerjaan dan kondisi pandemi.

Banyak penelitian telah dilakukan untuk menghitung dan menganalisasi beban kerja yang terdampak dari suatu pekerjaan. Penelitian ini dilakukan untuk menghitung beban kerja psikologis bagian marketing, khususnya untuk kategori manajer dengan total 12 (dua belas) responden. Metode yang digunakan adalah dengan pendekatan subjektif menggunakan framework dari National Aeronautics and Space Administration Task Load Index (NASA TLX).

\section{Landasan Teori}

\subsection{Beban Kerja Manual}

Manusia dalam bekerja secara umum melibatkan dua aktivitas utama, yaitu aktivitas fisik dan mental. Sebagian pekerjaan didominasi oleh aktivitas fisik, sedangkan sebagian lagi melibatkan aktivitas mental. Sebagai contoh, tugas pengangkatan beban secara manual didominasi oleh aktivitas fisik, sedangkan tugas perumusan strategi bisnis didominasi aktivitas mental. Salah satu isu yang menjadi fokus kajian dalam ilmu ergonomi adalah terkait beban mental manusia.

Young dan Stanton mendefinisikan beban kerja mental sebagai level sumber daya atensi atau perhatian yang dibutuhkan untuk memenuhi kriteria kinerja objektif maupun subjektif, yang 
muncul karena adanya tuntutan tugas, dukungan eksternal, dan pengalaman masa lalu [2]. Setidaknya terdapat dua teori terkait dengan definisi beban kerja mental. Dalam satu teori, beban kerja mental dilihat sebagai tuntutan pekerjaan yang merupakan variabel eksternal independen yang harus dipenuhi pekerja. Sudut pandang ini didominasi oleh tuntutan untuk melakukan perancangan tugas, terutama tugas baru yang belum perna hada sebelumnya. Dalam teori yang lain, beban kerja mental dilihat sebagai interaksi antara tuntutan pekerjaan dan kapabilitas manusia. Sudut pandang ini melihat adanya keberagaman manusia dalam merespon tugas dengan kondisi dan tuntutan yang sama.

Beban kerja mental merupakan sesuatu yang kompleks. Aktivitas mental selalu dibarengi dengan aktivitas fisik. Aktivitas fisik juga akan mempengaruhi persepsi pekerja terhadap beban mental yang diterima. Selain itu, beban kerja mental juga memiliki interaksi yang tidak sederhana dengan tugas yang diberikan, maupun dengan performansi. Kompleksitas beban kerja mental membuat pengukuran beban kerja mental tidak dapat dilakukan secara sederhana. [3]

O’Donnel dan Eggemeier menuliskan beragam teknik pengukuran beban kerja mental menjadi tiga kategori, yaitu [2]:

1. Metode pengukuran subjektif

2. Metode pengukuran berbasis performansi

3. Metode pengukuran fisiologis.

\subsection{NASA TLX (Task Load Index)}

NASA TLX dikembangkan oleh Hart dan Staveland pada tahun 1998 [4]. NASA TLX merupakan salah satu metode pengukuran secara subjektif. Pengukuran alat ini sangat luas karena selain mampu mengukur beban kerja dari berbagai dimensi, penggunaannya juga relatif mudah. Pada NASA TLX, partisipan diminta untuk mengisi rating dari enam aspek yang berbeda. Masing-masing aspek memiliki skala yang direpresentasikan dalam garis sepanjang $10 \mathrm{~cm}$ yang dibagi kedalam 20 internal. Rating untuk masing-masing aspek kemudian dikonversi ke dalam skala $0-100$.

Menurut Hart dan Staveland [5], enam aspek atau dimensi yang dimaksud, adalah:

1. Dimensi Mental (MD), adalah seberapa banyak aktivitas mental dan perseptual yang dibutuhkan (contoh: proses berpikir, memutuskan, mengingat, mencari, dan lain-lain). Apakah tugas termasuk mudah atau sulit, sederhana atau kompleks?

2. Dimensi Fisik (PD), adalah seberapa banyak aktivitas fisik yang dibutuhkan (contoh: menarik, mengangkat, dan lain-lain). Apakah tugas termasuk mudah atau sulit, lambat atau cepat, ringan atau berat?

3. Dimensi Waktu (TD), adalah berapa banyak tekanan waktu yang dirasakan? Apakah tempo dari pekerjaan termasuk lambat dan santai, atau cepat dan tergesa-gesa? 
4. Dimensi Kinerja (OP), adalah seberapa besar kesuksesan yang dirasakan dalam mencapai target yang ditentukan?

5. Dimensi Usaha (EF), adalah seberapa keras Anda harus bekerja (mental dan fisik) untuk mencapai tingkat kinerja yang diinginkan.

6. Dimensi Frustasi (FR), adalah seberapa besar tingkat frustasi yang muncul akibat pekerjaan? Apakah pekerjaan menimbulkan rasa tidak aman, kecil hati, jengkel, terganggu, atau sebaliknya. Apakah pekerjaan menimbulkan rasa aman, puas, dan santai.

NASA TLX memiliki beberapa kelebihan, yaitu pengukuran secara multidimensional, cepat dan sederhana dalam proses penyajian data, dan biaya penelitian yang murah, tetapi memiliki nilai sensitivitas yang tinggi. NASA TLX selain digunakan untuk pengukuran beban kerja mental pada perusahaan manufaktur, metode ini juga cocok dikembangkan dalam pengukuran beban kerja perusahaan jasa.

\section{Metodologi Penelitian}

Penelitian ini dilakukan dengan pendekatan subjektif menggunakan metode NASA TLX. Teknik pengambilan dan pengumpulan data menggunakan dua model kuesioner, yaitu: kuesioner pembobotan (weight), dan kuesioner pemberian peringkat (rating scale) [6].

\subsection{Flow Chart Penelitian}

Langkah-langkah penelitian yang dilaksanakan dapat dilihat pada diagram atau gambar berikut:

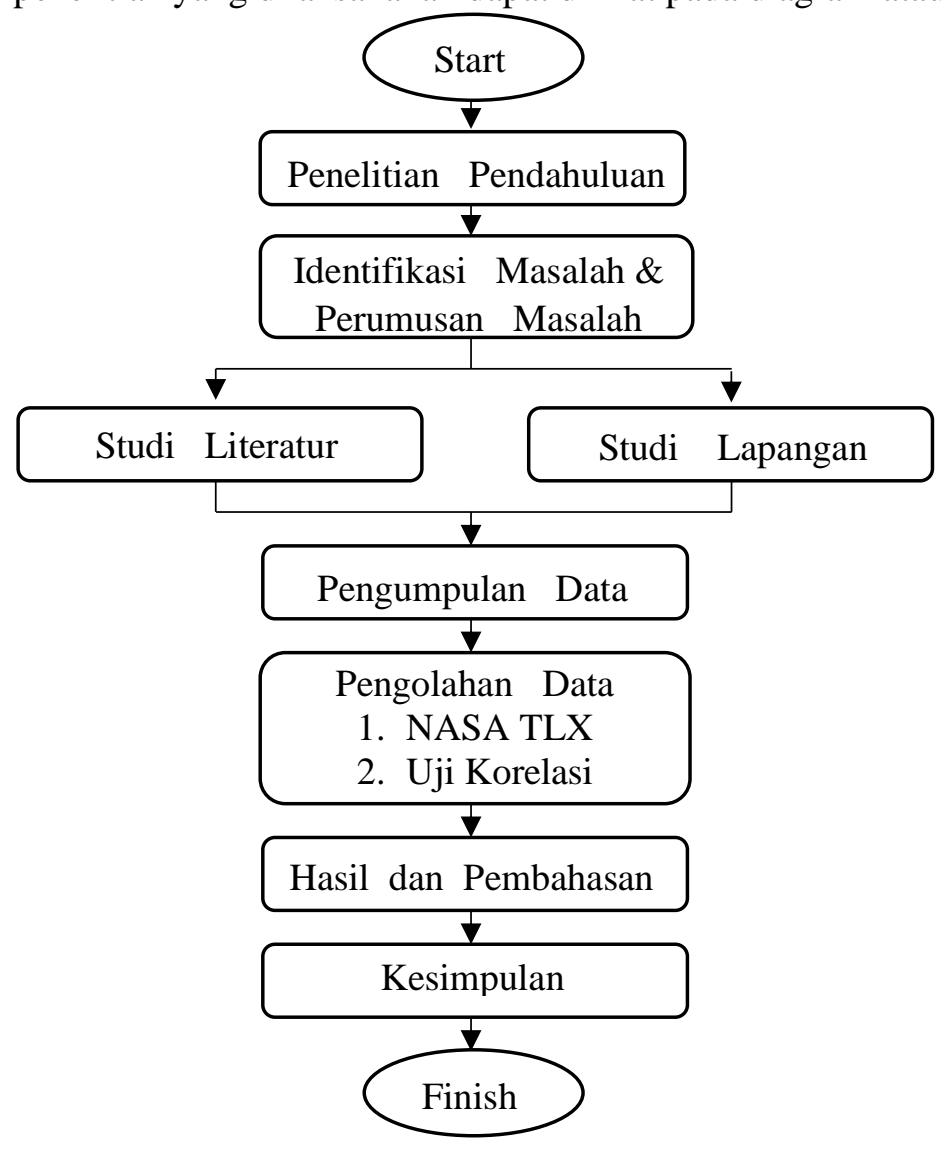

Gambar 1 Flow Chart Penelitian 


\subsection{Kuesioner NASA-TLX}

Menurut Meshkati, urutan-urutan pengumpulan data dengan NASA TLX, yaitu [7]:

\section{A. Kuesioner Pembobotan}

Kuesioner pembobotan diberikan kepada 12 responden yang telah ditetapkan. Partisipan memilih satu dari dua dimensi yang berpasangan. Sebagian orang menyebutnya dengan istilah kartu berpasangan. Ada 15 (lima belas) kartu pasangan/ perbandingan yang merupakan kombinasi dari 6 faktor indikator pembebanan kerja [7].

\begin{tabular}{|c|c|}
\hline $\begin{array}{c}\text { Tingkat Usaha (EF) } \\
\text { atau } \\
\text { Performansi (OP) }\end{array}$ & $\begin{array}{c}\text { Tuntutan Waktu (TD) } \\
\text { atau } \\
\text { Tingkat Frustasi (FR) }\end{array}$ \\
\hline $\begin{array}{c}\text { Tuntutan Waktu (TD) } \\
\text { atau } \\
\text { Tingkat Usaha (EF) }\end{array}$ & $\begin{array}{c}\text { Tuntutan Fisik (PD) } \\
\text { atau }\end{array}$ \\
\hline $\begin{array}{c}\text { Performansi (OP) } \\
\text { atau } \\
\text { Tingkat Frustasi (FR) }\end{array}$ & Tingkat Frustasi (FR) \\
\hline $\begin{array}{c}\text { Tuntutan Fisik (PD) } \\
\text { atau } \\
\text { Performansi (OP) }\end{array}$ & $\begin{array}{c}\text { atau } \\
\text { Tuntutan Waktu (TD) }\end{array}$ \\
\hline $\begin{array}{c}\text { Tingkat Frustasi (FR) } \\
\text { atau }\end{array}$ & $\begin{array}{c}\text { Tuntutan Waktu (TD) } \\
\text { atau }\end{array}$ \\
\hline Tingkat Usaha (EF) & Tuntutan Mental (MD) \\
\hline $\begin{array}{c}\text { Performansi (OP) } \\
\text { atau }\end{array}$ & $\begin{array}{c}\text { Performansi (OP) } \\
\text { atau }\end{array}$ \\
\hline Tuntutan Waktu (TD) & Tuntutan Mental (MD) \\
\hline $\begin{array}{c}\text { Tuntutan Mental (MD) } \\
\text { atau }\end{array}$ & $\begin{array}{c}\text { Tuntutan Mental (MD) } \\
\text { atau }\end{array}$ \\
\hline $\begin{array}{c}\text { Tuntutan Fisik (PD) } \\
\text { Tingkat Frustasi (FR) } \\
\text { atau }\end{array}$ & Tingkat Usaha (EF) \\
\hline $\begin{array}{c}\text { Tuntutan Mental (MD) } \\
\text { atau }\end{array}$ \\
\hline
\end{tabular}

Gambar 2 Kuesioner Pembobotan

\section{B. Kuesioner Pemberian Peringkat}

Tahap selanjutnya adalah pemberian peringkat (rating) dalam tahap ini partisipan diminta memberikan skor dengan skala 0-100 terhadap 6 (enam) indikator beban kerja. Skor yang diisi merupakan penilaian subjektif partisipan terhadap pekerjaan yang dilakukan [7].

1. Tuntutan Mental (MD)

Seberapa besar tuntutan aktivitas mental dan perseptual yang dibutuhkan dala, pekerjaan (seperti: berfikir, memutuskan, menghitung, mengingat, melihat, mencari, dsb)? Apakah pekerjaan tersebut mudah atau sulit; sederhana atau kompleks; longgar atau ketat, pasti atau perlu penafsiran?

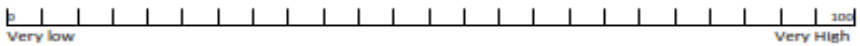

2. Tuntutan Fisik (PD)

Seberapa besar aktivitas fisik yang dibutuhkan dalam pekerjaan (seperti: mendorong, menarik, memutar, mengontrol, dsb)? Apakah pekerjaan tersebut mudah atau sulit; pelan atau cepat, statis terus-menerus atau ada waktu untuk istirahat?

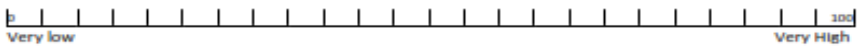

3. Tuntutan Waktu (TD)

Seberapa besar tekanan waktu yang dirasakan selama pekerjaan berlangsung? Apakah pekerjaan tersebut dilakukan dengan pelan-pelan dan santai, atau cepat dan melelahkan?

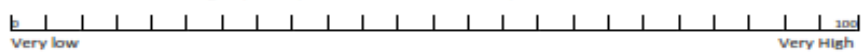

4. Tingkat Performansi (OP)

Seberapa besar keberhasilan di dalam mencapai target pekerjaan? Apakah Anda merasa puas dengan performansi di dalam mencapai target tersebut?

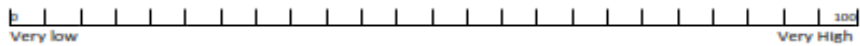

5. Tingkat Usaha (EF)

Seberapa besar usaha yang dikeluarkan baik secara mental dan fisik yang dibutuhkan untuk menyelesaikan pekerjaan pada level performansi?

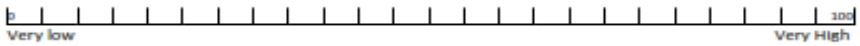

6. Tingkat Frustasi (FR)

Seberapa besar rasa tidak aman, putus asa, tersinggung, merasa tidak diperhatikan, stres dan terganggu dibandingkan dengan perasaan aman, puas, cocok, merasa diperhatikan, rileks, dan nyaman selama mengerjakan pekeriaan tersebut?

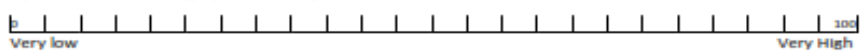

Gambar 3 Kuesioner Pemberian Peringkat 


\subsection{Pengolahan Data NASA TLX}

Urutan pengolahan data metode NASA TLX, yaitu [8]:

\section{A. Menghitung Produk}

Produk adalah hasil kali bobot dengan rating. Dihitung untuk enam dimensi beban mental (MD, PD, TD, OP, EF, FR).

$$
\text { Produk }=\text { Bobot } \times \text { Rating }
$$

\section{B. $\quad$ Menghitung nilai WWL (Weighted Workload)}

WWL adalah hasil jumlah dari keenam nilai produk.

$$
\mathrm{WWL}=\sum \text { Produk }
$$

\section{Menghitung Skor NASA TLX}

Skor NASA-TLX adalah nilai rata-rata WWL, yaitu hasil bagi WWL dengan total bobot $($ total bobot $=15)$.

$$
\text { Skor NASA TLX }=\frac{W W L}{15}
$$

\section{Kategori Skor NASA TLX}

Menurut Hart and Staveland, skor NASA TLX dapat dikategorikan tingkat beban kerja mentalnya [9]. Ada lima kelas internal yang dapat digunakan untuk pengkategorian beban kerja mental seseorang atau beban mental kelompok suatu jenis pekerjaan.

Tabel 1 Kategori Nilai Skor NASA TLX

\begin{tabular}{ccc}
\hline No & Interval Skor & Kategori Beban Kerja Mental \\
\hline 1 & $0-20$ & Sangat Rendah \\
2 & $21-40$ & Rendah \\
3 & $41-60$ & Sedang \\
4 & $61-80$ & Tinggi \\
5 & $81-100$ & Sangat Tinggi \\
\hline
\end{tabular}

\subsection{Uji Korelasi}

Uji korelasi dipakai untuk mengetahui apakah dua variabel memiliki hubungan atau tidak. Uji korelasi yang dipakai pada penelitian ini adalah uji korelasi koefisien Cramer, yaitu untuk menguji hubungan antara dua variabel yang berdata nominal (angka) [10]. 


\section{Hasil dan Pembahasan}

\subsection{Pengumpulan Data}

\section{A. Data Responden}

Penelitian dilakukan pada bulan Agustus 2020 di Departemen Marketing PT. Pindo Deli untuk kategori atau level Manager. Pengambilan data dilakukan dengan penyebaran kuesioner kepada dua belas partisipan, yaitu: enam orang dengan jabatan Regional Manager (RM), dan enam orang dengan jabatan Product Manager (PM).

Tabel 2 Data Responden

\begin{tabular}{clcccc}
\hline No & Nama & Jabatan & L/P & $\begin{array}{c}\text { Usia } \\
\text { (Tahun) }\end{array}$ & $\begin{array}{c}\text { Masa Kerja } \\
\text { (Tahun) }\end{array}$ \\
\hline 1 & RS & RM & L & 43 & 15 \\
2 & HP & RM & L & 44 & 18 \\
3 & FF & RM & L & 38 & 14 \\
4 & M & RM & P & 44 & 21 \\
5 & E & RM & L & 51 & 23 \\
6 & BW & RM & L & 41 & 10 \\
7 & NR & PM & L & 41 & 23 \\
8 & AS & PM & L & 38 & 10 \\
9 & EH & PM & L & 46 & 21 \\
10 & AH & PM & L & 53 & 26 \\
11 & SK & PM & L & 37 & 5 \\
12 & MPS & PM & P & 31 & 6 \\
\hline
\end{tabular}

Dari Tabel 2, data responden dapat digambarkan berdasarkan kelompok usia (Gambar 4), dan kelompok masa kerja (Gambar 5).

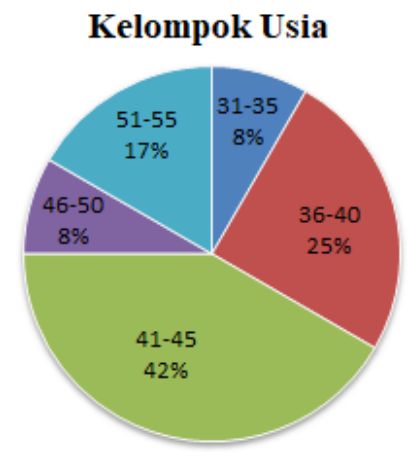

Gambar 4 Usia Responden

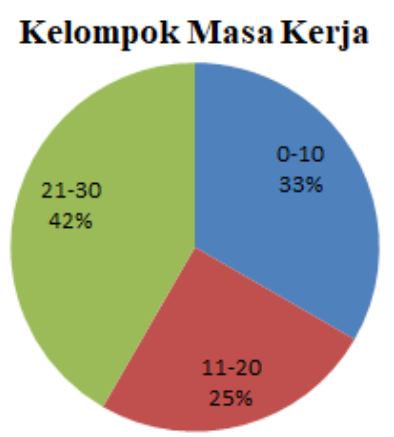

Gambar 5 Masa Kerja Responden

Secara sebaran data penulis menilai kondisi responden sudah sangat representatif untuk dapat dikaji dan dianalisa, baik secara usia maupun masa kerja seluruh responden memiliki tingkat kematangan emosi dalam setiap pengambilan keputusan dalam pekerjaan yang dilakukannya. 


\section{B. Data Hasil Kuesioner NASA TLX}

Terdapat 2 bagian kuesioner yang diukur, yaitu: pembobotan (weight), dan pemberian peringkat (rating scale). Hasil pembobotan dari 12 responden dapat dilihat pada Tabel 3.

Tabel 3 Nilai Pembobotan Indikator

\begin{tabular}{|c|c|c|c|c|c|c|c|c|c|}
\hline \multirow{2}{*}{ No } & \multirow{2}{*}{ Nama } & \multirow{2}{*}{ Jabatan } & \multicolumn{6}{|c|}{ Indikator } & \multirow{2}{*}{ Total } \\
\hline & & & MD & PD & TD & OP & EF & FR & \\
\hline 1 & $\mathrm{RS}$ & $\mathrm{RM}$ & 3 & 0 & 5 & 1 & 3 & 3 & 15 \\
\hline 2 & HP & RM & 1 & 2 & 5 & 3 & 4 & 0 & 15 \\
\hline 3 & FF & RM & 1 & 1 & 3 & 4 & 5 & 1 & 15 \\
\hline 4 & M & RM & 3 & 0 & 5 & 1 & 4 & 2 & 15 \\
\hline 5 & $\mathrm{E}$ & RM & 3 & 0 & 5 & 4 & 2 & 1 & 15 \\
\hline 6 & BW & RM & 2 & 1 & 4 & 5 & 3 & 0 & 15 \\
\hline 7 & NR & PM & 4 & 0 & 3 & 5 & 2 & 1 & 15 \\
\hline 8 & AS & PM & 5 & 0 & 2 & 4 & 2 & 2 & 15 \\
\hline 9 & EH & PM & 3 & 1 & 2 & 5 & 4 & 0 & 15 \\
\hline 10 & $\mathrm{AH}$ & PM & 3 & 1 & 4 & 5 & 2 & 0 & 15 \\
\hline 11 & SK & PM & 1 & 3 & 1 & 4 & 5 & 1 & 15 \\
\hline 12 & MPS & PM & 4 & 0 & 1 & 5 & 3 & 2 & 15 \\
\hline
\end{tabular}

Dari Tabel 3 dapat diketahui perolehan bobot terendah ada pada dimensi fisik (PD) dan dimensi frustasi (FR), hal ini menunjukan bahwa pekerjaan yang mereka lakukan tidak membutuhkan kapasitas fisik yang tinggi, dan menjadikan stres atau frustasi dalam bekerja. Sementara berdasarkan jabatan: untuk RM lebih dominan pada dimensi waktu (TD) yaitu kebutuhan waktu, kecepatan kerja, date line dalam pemenuhan order setiap bulannya, sedangkan untuk PM lebih dominan pada dimensi kinerja (OP) yaitu menunjukan seberapa besar kepuasan pekerja dalam pemenuhan target, atau dengan kata lain orientasi pada hasil.

Tahap selanjutnya adalah adalah penentuan peringkat (rating scale). Rating Scale adalah alat numerik yang bertujuan untuk mendapatkan hal-hal yang merefleksikan faktor kerja yang dirasakan pekerja. Hasil pemberian peringkat dari 12 responden dapat dilihat pada Tabel 4 , sebagai berikut:

Tabel 4 Nilai Pemberian Peringkat

\begin{tabular}{cllcccccc}
\hline \multirow{2}{*}{ No } & \multirow{2}{*}{ Nama } & \multirow{2}{*}{ Jabatan } & \multicolumn{7}{c}{ Indikator } \\
\cline { 4 - 8 } & & MD & PD & TD & OP & EF & FR \\
\hline 1 & RS & RM & 95 & 80 & 99 & 90 & 99 & 80 \\
2 & HP & RM & 90 & 80 & 95 & 95 & 100 & 65 \\
3 & FF & RM & 70 & 50 & 50 & 90 & 90 & 50 \\
4 & M & RM & 90 & 30 & 99 & 90 & 99 & 70 \\
5 & E & RM & 90 & 10 & 90 & 90 & 90 & 10 \\
6 & BW & RM & 70 & 40 & 80 & 90 & 70 & 60 \\
7 & NR & PM & 85 & 10 & 80 & 90 & 80 & 30 \\
8 & AS & PM & 90 & 40 & 80 & 80 & 90 & 50 \\
9 & EH & PM & 100 & 30 & 90 & 100 & 100 & 30 \\
10 & AH & PM & 95 & 30 & 95 & 95 & 98 & 60 \\
11 & SK & PM & 80 & 50 & 80 & 100 & 80 & 50 \\
12 & MPS & PM & 80 & 20 & 30 & 80 & 80 & 60 \\
\hline
\end{tabular}


Dapat diketahui dari Tabel 4, sebagian besar responden baik untuk jabatan RM maupun PM nilai pemberian peringkat terendah adalah dimensi fisik (PD) yaitu tuntukan fisik artinya semua responden sepakat bahwa pekerjaan yang mereka lakukan tidak memerlukan aktivitas fisik yang tinggi, tidak ada aktivitas seperti: mendorong, memutar, menarik, mengontrol, dan lain sebagainya.

\subsection{Pengolahan Data}

\section{A. Perhitungan Skor NASA TLX}

Setelah data kuesioner NASA TLX direkap, kemudian dilakukan perhitungan skor NASA TLX, yang dapat dilakukan dengan menggunakan rumus (1), (2), dan (3). Berikut adalah contoh perhitungan Nilai Produk, WWL dan Skor NASA TLX untuk data responden nomor 1 (RS), berdasarkan data yang sudah berhasil dikumpulkan pada tahap sebelumnya.

1. Menghitung Nilai Produk

$\begin{array}{llll}\text { Produk MD } & =\text { Bobot MD x Rating MD } & =3 \times 95 & =285 \\ \text { Produk PD } & =\text { Bobot PD } \times \text { Rating PD } & =0 \times 80 & =0 \\ \text { Produk TD } & =\text { Bobot TD } \times \text { Rating TD } & =5 \times 99 & =495 \\ \text { Produk OP } & =\text { Bobot OP } \times \text { Rating OP } & =1 \times 90 & =90 \\ \text { Produk EF } & =\text { Bobot EF x Rating EF } & =3 \times 99 & =297 \\ \text { Produk FR } & =\text { Bobot FR x Rating FR } & =3 \times 80 & =240\end{array}$

2. Menghitung Weighted Work Load (WWL)

$W W L=\sum$ Produk $=285+0+495+90+297+240=1.407$

3. Menghitung Skor NASA TLX

Skor

$$
=\frac{W W L}{15} \quad=\frac{1.407}{15}=93,8
$$

Sementara hasil perhitungan untuk responden lainnya, dapat dilihat pada rekapitulasi Tabel 5.

Tabel 5 Nilai Produk, Weighted Work Load (WWL), dan Skor NASA TLX

\begin{tabular}{clcccccccc}
\hline \multirow{2}{*}{ No Nama } & & \multicolumn{9}{c}{ Indikator } & \multirow{2}{*}{ WWL } & Skor NASA \\
\cline { 3 - 7 } & & MD & PD & TD & OP & EF & FR & & TLX \\
\hline 1 & RS & 285 & 0 & 495 & 90 & 297 & 240 & 1.407 & 93,8 \\
2 & HP & 90 & 160 & 475 & 285 & 400 & 0 & 1.410 & 94,0 \\
3 & FF & 70 & 50 & 150 & 360 & 450 & 50 & 1.130 & 75,3 \\
4 & M & 270 & 0 & 495 & 90 & 396 & 140 & 1.391 & 92,7 \\
5 & E & 270 & 0 & 450 & 360 & 180 & 10 & 1.270 & 84,7 \\
6 & BW & 140 & 40 & 320 & 450 & 210 & 0 & 1.160 & 77,3 \\
7 & NR & 340 & 0 & 240 & 450 & 160 & 30 & 1.220 & 81,3 \\
8 & AS & 450 & 0 & 160 & 320 & 180 & 100 & 1.210 & 80,7 \\
9 & EH & 300 & 30 & 180 & 500 & 400 & 0 & 1.410 & 94,0 \\
10 & AH & 285 & 30 & 380 & 475 & 196 & 0 & 1.366 & 91,1 \\
11 & SK & 80 & 150 & 80 & 400 & 400 & 50 & 1.160 & 77,3 \\
12 & MPS & 320 & 0 & 30 & 400 & 240 & 120 & 1.110 & 74,0 \\
\hline
\end{tabular}

Weighted Work Load (WWL) adalah skor beban kerja mental yang merupakan penjumlahan skor atau nilai produk dari 6 faktor (MD, PD, TD, OP, EF, dan FR). [7] Rata-rata WWL ini yang kita 
sebut sebagai skor NASA-TLX, didapat dari pembagian skor beban kerja mental dibagi 15 (jumlah perbandingan faktor berpasangan).

Berdasarkan Tabel 5, dapat dilihat bahwa nilai produk tiap-tiap indikator masing-masing responden sangat bervariasi, nilai produk terendah adalah nol dan nilai tertinggi adalah 500, yaitu untuk indikator tingkat performansi (OP), menunjukkan responden atas nama $\mathrm{EH}$ bekerja pada pencapaian target, yang bersangkutan akan merasa sukses/ puas pada hasil pekerjaan apabila targetnya tercapai, dan sebaliknya yang bersangkutan akan merasa kecewa apabila hasilnya tidak mencapai target. Nilai tertinggi (500), tersebut merupakan hasil perkalian nilai bobot indikator OP $(=5$, bobot maksimal) dari kuesioner pembobotan dengan nilai peringkat indikator OP $(=100$, skor maksimal) dari kuesioner pemberian peringkat. Nilai ini juga menunjukkan nilai beban kerja mental (mental workload) untuk salah satu indikator.

Pada kolom skor NASA TLX dari 12 responden, semuanya menunjukkan angka diatas normal, dimana batas normalnya berada pada level skor 60. Skor ini menunjukan katergori beban kerja mental yang dirasakan para manajer marketing PT. Pindo Deli Pulp dalam bekerja dimasa pandemi Covid-19.

\section{B. Pengkategorian Beban Kerja Mental}

Kategori beban kerja mental dapat dilakukan membandingkan skor NASA TLX dengan Tabel 1. Berikut adalah level beban kerja mental yang dialami oleh 12 orang manajer pada masa pandemik COVID-19.

Tabel 6 Kategori Beban Kerja Mental

\begin{tabular}{clccc}
\hline No & Nama & Jabatan & $\begin{array}{c}\text { Skor } \\
\text { NASA TLX }\end{array}$ & $\begin{array}{c}\text { Kategori } \\
\text { Beban Kerja Mental }\end{array}$ \\
\hline 1 & RS & RM & 93,8 & Sangat Tinggi \\
2 & HP & RM & 94,0 & Sangat Tinggi \\
3 & FF & RM & 75,3 & Tinggi \\
4 & M & RM & 92,7 & Sangat Tinggi \\
5 & E & RM & 84,7 & Sangat Tinggi \\
6 & BW & RM & 77,3 & Tinggi \\
7 & NR & PM & 81,3 & Sangat Tinggi \\
8 & AS & PM & 80,7 & Tinggi \\
9 & EH & PM & 94,0 & Sangat Tinggi \\
10 & AH & PM & 91,1 & Sangat Tinggi \\
11 & SK & PM & 77,3 & Tinggi \\
12 & MPS & PM & 74,0 & Tinggi \\
\hline
\end{tabular}

Persentase responden berdasarkan tingkat beban kerja mental secara grafik adalah: 


\section{Persentase Beban Kerja}

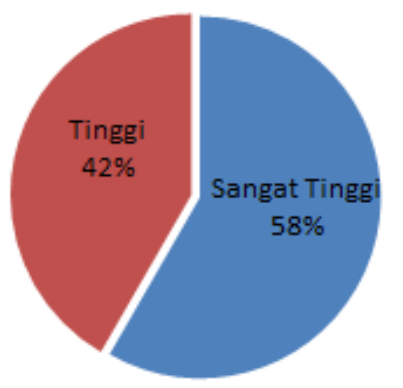

Gambar 6 Persentase Partisipan berdasarkan Tingkat Beban Kerja Mental

Secara keseluruhan beban kerja mental para manajer PT. Pindo Deli tergolong kategori diatas normal, dengan skor NASA TLX diatas level skor 60. Skor terrendah 74,0 dengan kategori beban kerja mental tinggi, dan skor tertingginya adalah 94,0 dengan kategori beban kerja mental sangat tinggi. Secara persentase menunjukan bahwa $42 \%$ pada kategori beban kerja mental tinggi dan sisanya 58\% kategori beban kerja mental sangat tinggi.

\subsection{Uji Korelasi}

Uji korelasi yang dipakai adalah uji korelasi koefisien Cramer. Ada 2 (dua) uji korelasi yang dilakukan yaitu: hubungan antara usia dengan tingkat beban kerja mental, dan hubungan masa kerja dengan tingkat beban kerja mental.

Usia * Kategori_Beban_Kerja Crosstabulation

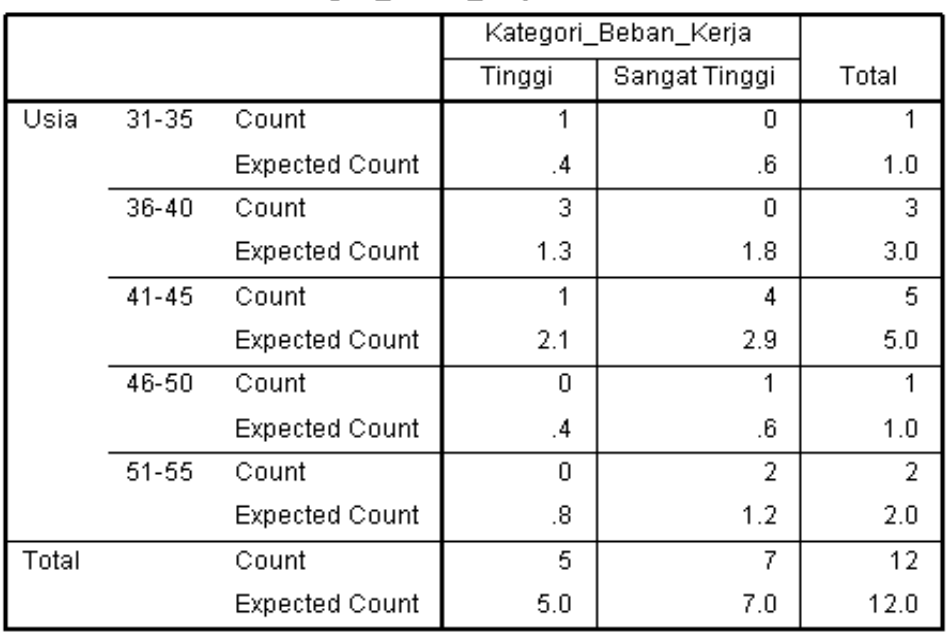

Symmetric Measures

\begin{tabular}{|ll|r|r|}
\hline & & \multicolumn{1}{|c|}{ Value } & Approx. Sig. \\
\hline Nominal by Nominal & Phi & .852 & .069 \\
& Cramer's $V$ & .852 & .069 \\
& Contingency Coefficient & .648 & .069 \\
$N$ Nof Valid Cases & & 12 & \\
\hline
\end{tabular}

Gambar 7 Uji Korelasi Usia dengan Tingkat Beban Kerja Mental 
Lihat pada kolom Approximate Significance (Sig) dimana nilai sig pada Phi, Cramer's V, dan Contingency Coefficient adalah 0,069 >0,05 artinya tidak terdapat hubungaan antara usia dengan tingkat beban kerja mental.

\begin{tabular}{|c|c|c|c|c|c|}
\hline & & & Kategor & Beban_Kerja & \multirow[b]{2}{*}{ Total } \\
\hline & & & Tinggi & Sangat Tinggi & \\
\hline \multirow[t]{6}{*}{ Masa_Kerja } & $0-10$ & Count & 4 & 0 & 4 \\
\hline & & Expected Count & 1.7 & 2.3 & 4.0 \\
\hline & $11-20$ & Count & 1 & 2 & 3 \\
\hline & & Expected Count & 1.3 & 1.8 & 3.0 \\
\hline & $21-30$ & Count & 0 & 5 & 5 \\
\hline & & Expected Count & 2.1 & 2.9 & 5.0 \\
\hline \multirow[t]{2}{*}{ Total } & & Count & 5 & 7 & 12 \\
\hline & & Expected Count & 5.0 & 7.0 & 12.0 \\
\hline
\end{tabular}

Symmetric Measures

\begin{tabular}{|ll|r|r|}
\hline & & \multicolumn{1}{|c|}{ Value } & Approx. Sig. \\
\hline Nominal by Nominal & Phi & .878 & .010 \\
& Cramer's V & .878 & .010 \\
& Contingency Coefficient & .660 & .010 \\
\multirow{2}{*}{$N$ of Valid Cases } & & 12 & \\
\hline
\end{tabular}

Gambar 8 Uji Korelasi Masa Kerja dengan Tingkat Beban Kerja Mental

Lihat pada kolom Approximate Significance (Sig) dimana nilai sig pada Phi, Cramer's V, dan Contingency Coefficient adalah 0,01 $<0,05$ artinya terdapat hubungaan antara masa kerja dengan tingkat beban kerja mental.

\subsection{Pembahasan}

Berdasarkan Gambar 6 data menunjukan sebanyak 5 (lima) orang manajer atau $42 \%$ berada pada level beban kerja mental tinggi, dan sebanyak 7 (tujuh) orang manajer atau 58\% berada pada level beban kerja mental sangat tinggi.

Jika dilihat pada Tabel 6, berdasarkan analisa pada 6 (enam) dimensional yaitu: Mental (DM), Fisik (PD), Waktu (MD), Kinerja (OP), Usaha (EF), dan Frustasi (FR) yang menjadi indikator perhitungan skor NASA TLX, terdapat perbedaan dimensional/faktor yang paling dominan yang mempengaruhi tingkat beban kerja mental antara jabatan Regional Manager (RM) dan Product Manager (PM).

Untuk Regional Manager (RM) dimensional yang paling dominan mempengaruhi tingkat beban kerja mental adalah dimensi waktu (TD), karena tekanan yang berkaitan dengan kebutuhan waktu yaitu kecepatan dan tempo menyelesaikan suatu pekerjaan. 
Untuk Product Manager (PM) dimensional yang paling dominan mempengaruhi tingkat beban kerja mental adalah dimensi kinerja (OP) karena fokus mengejar tingkat keberhasilan dan kepuasan dari hasil kerja yang dilakukan.

\section{Kesimpulan}

Kesimpulan dari penelitian ini berdasarkan hasil dan pembahasan diperoleh sebanyak $42 \%$ manajer pada Departemen Marketing di PT. Pindo Deli memiliki level beban kerja mental kategori "tinggi" dan sisanya sebanyak $58 \%$ berada pada kategori "sangat tinggi". Berdasarkan Tabel 6 skor NASA TLX terrendah adalah 74,0 dan skor tertinggi 94,0 jauh diatas skor level untuk kategori beban normal (skor 60,0), ini menunjukkan bahwa para menajer pada masa pandemi Covid-19 mereka bekerja dengan beban psikologis yang luar biasa tinggi. Tingginya level beban kerja mental terjadi karena banyaknya tuntutan pekerjaan yang menjadi tanggungjawab para manajer dalam penjualan kertas setiap bulannya.

Untuk mengurangi dan atau menghindari dampak negatif dari beban kerja mental yang berlebih, terhadap kesehatan, penulis mengusulkan perlunya dilakukan konfirmasi terkait hasil penelitian ini dengan seluruh responden, sehingga langkah-langkah perbaikan baik waktu kerja, metode kerja, aktivitas kerja, dan lain-lainnya dapat dilakukan.

\section{DAFTAR PUSTAKA}

[1] S. Effendi, "Pandemi dan Disrupsi Perdagangan Internasional," Katadata.co.id, 2020.

[2] Yassierli, G. B. Pratama, D. A. Pujiartati, and P. A. R. Yamin, Ergonomi Industri. Cetakan Pertama, Bandung: Penerbit PT. Remaja Rosdakarya, 2020.

[3] H. Iridiastadi and Yassierli, Ergonomi Suatu Pengantar. PT. Remaja Rosdakarya, Bandung, 2015.

[4] S. G. Hart and L. E. Staveland, "Development of NASA-TLX (Task Load Index): Results oof Empirical and Theoretical Research.," Advances in psychology. pp. 139-183, 1998.

[5] S. Rubio, E. Diaz, and J. Martin, "Evaluation of Subjective Mental Workload: A Comparasion of SWAT, NASA-TLX, and Workload Profile Methods," Appl. Psychol., vol. 53, no. 1, pp. 61-86, 2004.

[6] Amri and Herizal, "Analisis Beban Kerja Psikologis dengan Menggunakan Metode NASA-TLX pada Operator Departemen Fiber Line di PT. Toba Pulp Lestari," Ind. Eng. J., vol. 6, no. 1, pp. 29-35, 2017.

[7] Tarwaka, Ergonomi Industri, Dasar-dasar Pengetahuan Ergonomi dan Aplikasi di Tempat Kerja, Edisi II. Surakarta: Harapan Press, 2015.

[8] Riono, Suparno, and A. Bandono, "Analysis of Mental Workload with Intergated NASA-TLX and Fuzzy Method," Int. J. ASRO, vol. 1, no. 1, pp. 37-45, 2018.

[9] D. Diniaty and M. Ikhsan, "Analisis Beban Kerja Mental Operator Produksi Pabrik Kelapa Sawit dengan Metode NASA-TLX di PT. Bina Pratama Sakato Jaya, Dharmasraya," J. Tek. Ind., vol. 1, no. 1, pp. 1-6, 2018.

[10] A. Gregorius, SPSS Komplet untuk Mahasiswa. Jakarta: Kompas Gramedia, 2018. 